\title{
THE OCCURRENCE OF PALAEOZOIC CONGLOMERATIC ROCKS IN EAST JOHOR, PENINSULAR MALAYSIA
}

\author{
Sugeng Sapto Surjono*1, Mohd Shafeea Leman ${ }^{2}$, Kamal Roslan Mohamed ${ }^{2}$, and Che Aziz \\ $\mathrm{Ali}^{2}$ \\ ${ }^{1}$ Department of Geological Engineering, Gadjah Mada University, Yogyakarta, Indonesia \\ ${ }^{2}$ School of Environmental Science and Natural Resources, Universiti Kebangsaan Malaysia, 43600 Bangi, Selangor, \\ Malaysia
}

\begin{abstract}
Conglomeratic rocks in East Johor are found in the separately three formations that are the Murau, Tanjung Leman and Linggiu Formations. The Murau Formation is characterized by cobble to boulder grained breccia with very angular to angular and disorganized clasts. It was deposited by fan-delta system in the sub-aerial to shallow marine environment. The Tanjung Leman Formation consists of pebble to cobble grained conglomerate with rounded to subrounded and organized clasts. It was deposited by braided river system in the sub-aerial environment. Both formations outcropped in eastern coastal of Johor. The rudaceous rocks of the Linggiu Formation consist of pebble to cobble-sized clasts with sub angular and disorganized texture. It present as subordinate rocks within sandstone dominant in the central part of East Johor and was deposited by debris flows in the shallow marine environment. All these rudaceous rocks were interpreted as Palaeozoic in age ranging from Late Carboniferous to Late Permian. Those rudaceous rocks indicated that since Late Carboniferous, palaeogeography of East Johor was a continent with subaerial to shallow marine depositional environment.
\end{abstract}

Keywords: Conglomerate, Palaeozoic, East Johor, subaerial, shallow marine.

${ }^{*}$ Corresponding author: S.S. SURJONO, Department of Geological Engineering, Faculty of Engineering, Gadjah Mada University, Jl. Grafika 2 Yogyakarta, 55281, Indonesia. E-mail: ssuryono@ugm.ac.id

\section{Introduction}

In East Johor, the Palaeozoic rocks consist mainly of metasedimentary to metamorphic, siliciclastic and volcanic rocks with age range from Carboniferous to Permian. These rocks can be divided into seven lithostratigraphic units including from the oldest, the Mersing, Murau, Dohol, Linggiu, Sedili, Pengerang and Tanjung Leman Formations. Rudaceous rocks including polimict breccias and conglomerates occur in the Murau, Tanjung Leman and Linggiu Formations (Figure 1). Each rudaceous rocks have special characteristics in sedimentary texture as well as sedimentary structures indicating different its sedimentary processes and depositional environments.

\section{Lithostratigraphy}

The Palaeozoic lithostratigraphy of East Johor is briefly discussed in the following section. Next discussion, however, will be focused on the rudaceous rocks in the Murau, Linggiu and Tanjung Leman Formations.

Mersing Formation This unit is regarded as representing the basement rock in Johor (Hutchison, 1989) which is mainly composed by slate, argillite, phyllite, schist, metaquartzite and quartzite. This rock unit is widely distributed in eastern Johor and southeastern 


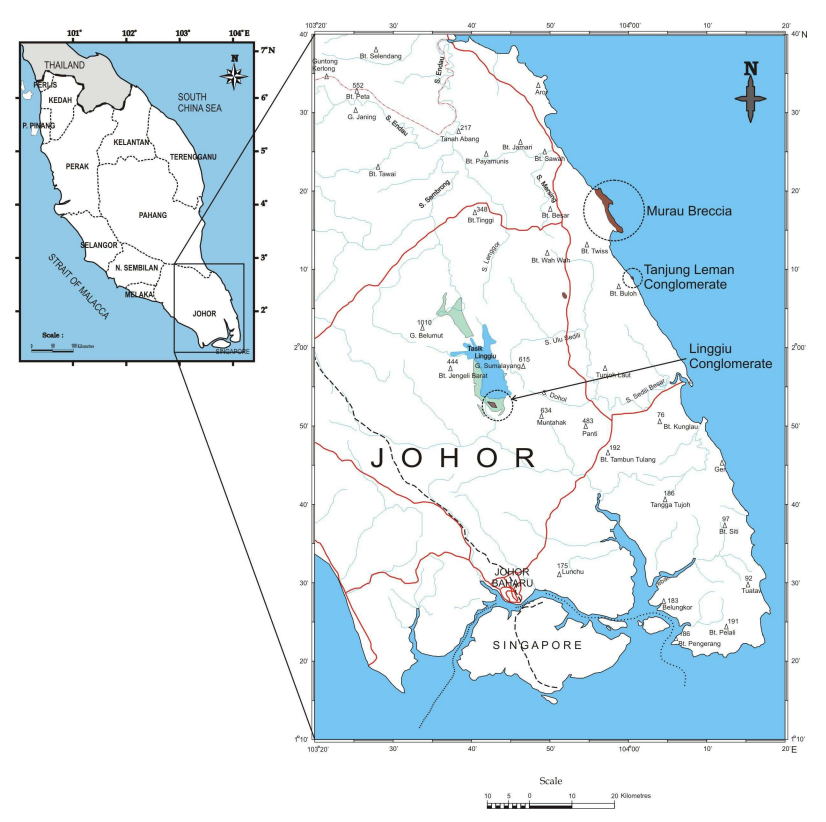

Figure 1: Distribution of conglomeratic rocks in East Johor

Pahang. This formation is interpreted to be Carboniferous in age, and all younger rocks formation in East Johor are found to be unconformably deposited over this formation.

Murau Formation It occupies eastern coast of Johor from the Tanjung Sekakap to Tanjung Tenggaroh. This formation comprises disorganized and thick breccia, gravelstone and sandstone forming thick rudaceous sequence. The age of this rock unit is interpreted as pre-Early Permian prior to volcanism in East Johor, possibly Late Carboniferous.

Dohol Formation This formation occurs mainly in eastern part of Gunung Sumalayang, within the upper reaches of Sungai Sedili and Sungai Dohol. This formation comprises interbedded of mudstone, shale, siltstone and sandstone with subordinate limestone. The age of the Dohol formation has been determined by Igo et al. (1979) as of late Early Permian to early Middle Permian. This formation was contemporaneously deposited with the Sedili Formation and conformably overlain by the Linggiu Formation.
Linggiu Formation The Linggiu Formation is well distributed in the west of Gunung Sumalayang area, generally west of the Dohol Formation. It is made up of sandstone, siltstone, shale, with subordinate conglomerate and tuffaceous sandstone. The age of this formation was assigned by Kon'no et al. (1971) to the Late Permian. This formation is interpreted to be a continuation of the Dohol formation which is stratigraphically interfingering with the Sedili formation.

Sedili Formation The formation is mostly distributed in the Gunung Sumalayang, Sungai Ulu Sedili and Gunung Chemendong areas. It is composed by lava, pyroclastic fall and flow deposits. The Sedili Formation interfingers with the Dohol and Linggiu Formations, thus all this formation were thought to be contemporaneously deposited during the Early to Late Permian.

Pengerang Formation The formation is distributed in the Pengerang area, southeast Johor. It is made up of rhyolitic to andesitic lava, and resedimented volcaniclastic deposits. The Pengerang Formation is probably equivalent to the upper part of Sedili formation.

Tanjung Leman Formation This formation is distributed in Tanjung Leman area, about ten kilometres south of Tanjung Tenggaroh. It is composed by interbedded of conglomerate, sandstone and mudstone. This formation is the youngest Palaeozoic rock unit in East Johor, interpreted to be equivalent to the topmost of Sedili formation.

\section{Murau Breccia}

The Murau Formation comprises polymodal breccia, sandy breccia, brecciatic sandstone, coarse sandstone, fossiliferous sandstone and mudstone. It is characterized by thick breccia and sandstone and its reddish colour especially when the rock is rich in sandstone or mudstone. Among clasts of breccia are quartzite, schist, phyllite, argillite, slate and quartz mineral (Figure 2). The volcanic clasts do not present in 


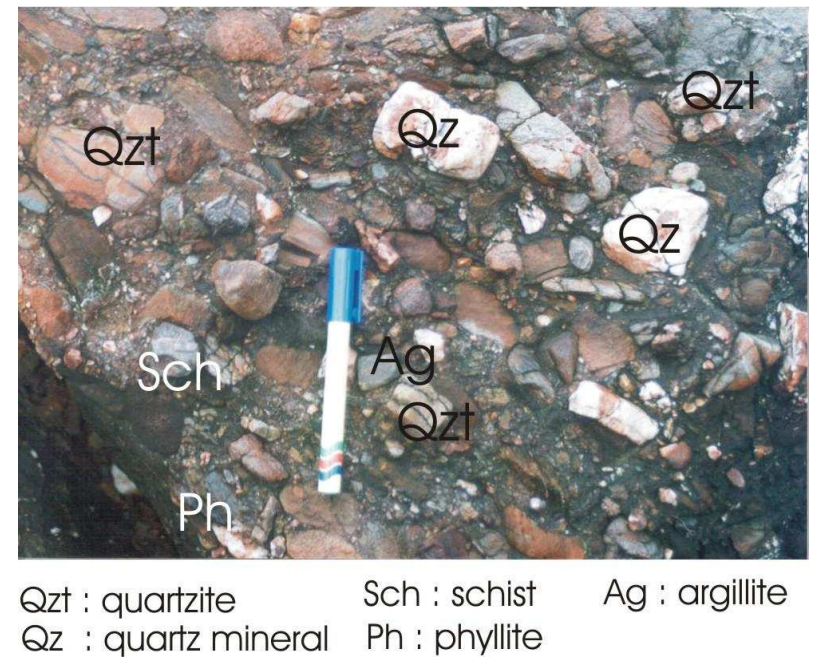

Figure 2: Polymict breccia of Murau Formation outcropped in Tanjung Sekakap

the Murau rocks, whether as fragment as well as matrix. The matrix in the breccia is mixture of coarse sandstone and finer grains including silt and clay size material. The composition of matrix in breccia resemble to their clasts that consist of lithic derived from metamorphic rocks. The detritals of Murau rocks were originated from the breakdown of Mersing Formation through the processes of weathering and erosion and subsequently deposited by fluid and/or sediment gravity flows. The cement of breccia and sandstone in Murau Formation is most probably iron oxide. It is recognized by the reddish colour that possibly resemble to commonly reddish sandstone identified by Prothero and Schwab (2004).

Surjono (2006a) have recognized the $\mathrm{Mu}-$ rau rudaceous rocks into ten sedimentary facies on the basis of its rocks type, sedimentary textures and structures, bedding contacts, bedding thickness as well as fossil contents. These sedimentary facies are the Disorganized, boulder-cobble supported breccia (facies $\mathrm{Bd}$ ), Crudely stratified cobble-boulder-rich breccia (facies Bs), Disorganized, clast-supported gravelstone (facies Gd), Crudely stratified cobble-rich gravelstone (facies Gs-1), Crudely stratified pebble-rich gravelstone (facies Gs-2), Normally-inversely graded gravelstone (facies Gn-i), Cross-bedded gravelstone (facies Gc), Stratified sandstone (facies Ss), Bioturbated sandstone (facies Sf) and Homogenous mudstone facies (facies Mh). These lithofacies is plotted in composite log of the Murau succession to interpret the sedimentary processes as well as their depositional environments.

The complete succession of Murau formation is summarized in Figure 3. In general, the lower part of the succession comprises of thickly bedded breccia with poorly sorted clasts and disorganized to crudely stratified bedding. This part is usually dominated by facies Bd and Bs of alluvial fan deposit (AF facies association). Towards the middle part of the succession, the facies gradually changes to interbedded of moderately to thickly-bedded gravelstone and very coarse sandstone. It is represented mainly by facies Gd, Gs-1 and Gs2 for gravelstone and facies Ss for sandstone. This part was deposited in Gilbert-type topsetforeset fan-delta (GTF facies association). In the upper part of the succession, the facies is characterized mainly by thickly bedded sandstone, pebbly sandstone and gravelstone with subordinate mudstone. This part can be further subdivided into three divisions. In its lower division, sandstone is dominant with subordinate gravelstone and bioturbated sandstone, represented by facies Ss, Sf and Gs-2. The middle division is characterized by alternating of sandsone, mudstone and breccia, sometimes with normal graded bedding. The facies in this middle division are facies Ss, Gs-2, Mh and Gn-i. In the topmost division, breccia is more dominant than sandstone, characterized by thickly bedded, cross-bedded and normally graded breccia intercalated by moderately bedded sandstone. Channel-fill gravelstone is also common within sandstone bedsets. The facies in this uppermost division are Gs-2, Gc, Gn-i and Ss. All this three subdivisions was deposited in the Gilbert-type topset fan delta (GT facies association). Thus, in general, the succession of Murau formation exhibit a continuous fining upward sequence from the base of the formation up to the middle division of the upper succession. Thereafter the succession seems to be showing a coarsening upward sequence up to the top of the formation.

Based on the discussion above, it is believed 


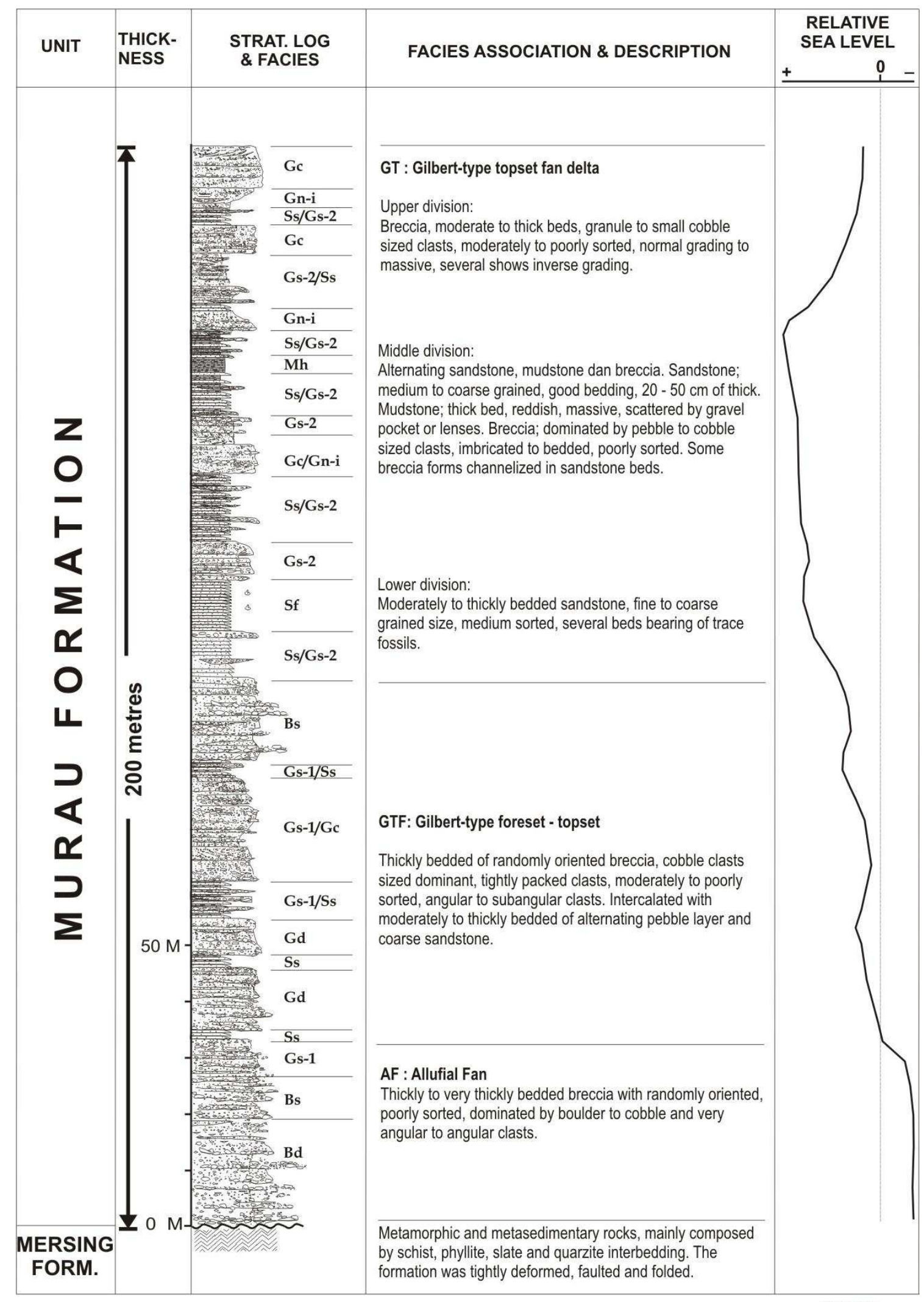

@Ss\$2005

Figure 3: Lithological log composite of the murau formation 
that the depositional environment of Murau formation had evolved from sub-aerial to shallow marine environments. The sub-aerial depositional environment is exhibited by AF facies association developed in the lower part succession (Figure 3). The shallow marine depositional environment is interpreted mainly based on the occurrence of bioturbated sandstone (facies Sf) discovered in Tanjung Sekakap. Compared to the bioturbation in Doumsan fan-delta (Chough et al., 1990), this particular bioturbation structure should represent brackish or shallow marine sediments. In general, the clasts of sediment will be finer to deeper depositional environment. Thus a generally fining upward facies succession indicates deeper depositional environments, i.e., from sub-aerial to shallow marine. However, at the topmost succession, it shows a shallower depositional environment.

\section{Linggiu Conglomerate}

Linggiu conglomerate is a subordinate within arenaceous and argillaceous component of Linggiu Formation, mainly occur in upper part succession. It occurs in association with massive sandstone as well as heterolithic facies in the upper part of the succession. This conglomerate is characterized by thickly bedded conglomerate varies from 3 to $8 \mathrm{~m}$ thick, crudely stratified to disorganized clasts, dark reddish in colour and with abrupt contact at the bottom. It is composed by clasts of metamorphic, sedimentary and volcanic rocks (Figure 4). Metamorphic rock clasts consist of argillite, slate, schist, phyllite and quartzite. The sedimentary rock clasts are mainly made of chert, mudstone and sandstone of reddish colour. This sandstone is similar to those of Murau Formation. The volcanic rock fragments are made of lapilli and lava. The matrix of conglomerate is made of poorly sorted sand and mud with dark colour. Based on the conglomerate classification proposed by Boggs (1992), the Linggiu conglomerate that consists of various lithoclasts belongs to polymict-clast conglomerate. The clasts generally subangular to subrounded grains, show randomly oriented or weakly imbricated fabric. The grain-matrix relationship is

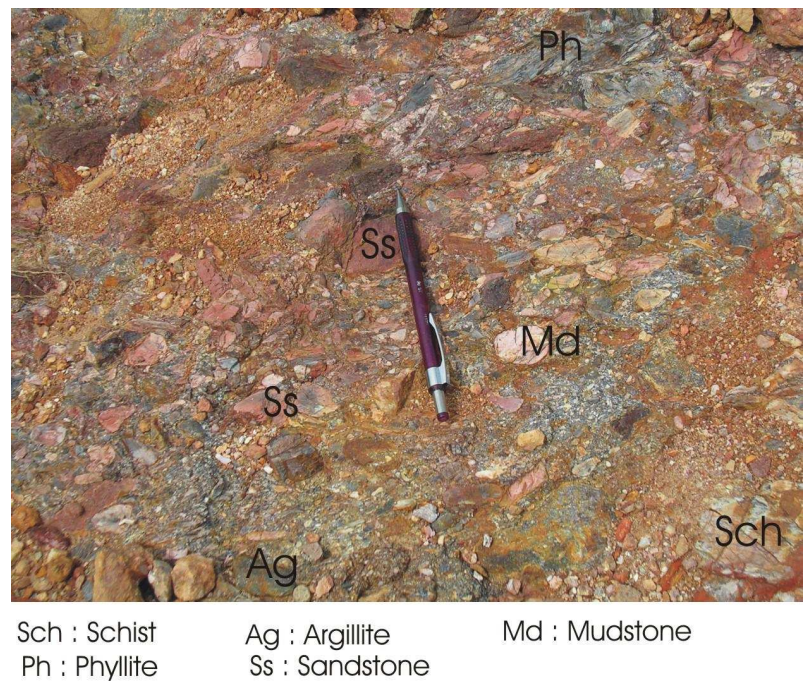

Figure 4: Polymict conglomerate of linggiu formation outcropped in Bukit Pachat

mainly matrix supported with floating grains and rare point contact.

Dott (1983, 1996) and Einsele (1996) suggested that conglomerate associated with massive sandstone as that in Linggiu Formation is possibly produced by under water debris flows as an event deposits. Considering its matrix supported, weak imbrication and its association with massive sandstone as well as heterolithic facies (Figure 5), this conglomerate was probably deposited through sudden fluid controlled debris flows reducing mass concentration. As Walker (1975) interpreted for the resedimented conglomerate, the Linggiu conglomerate possibly represent sediment that initially accumulates in an unconsolidated pile in shallow water that was subsequently resedimented into deeper water. The term deep water implies consistently below the storm wave base as suggested by Walker (1975). Raymond (1995) believed that such typical conglomerate was initiated where gravitational instability was created by large amount of rainfall in accumulated weathering products.

\section{Tanjung Leman Conglomerate}

The Tanjung Leman Conglomerate is distributed in mainly in Tanjung Leman, East Johor. It is located about 10 kilometres south of Tanjung Tenggaroh (Figure 1). The conglom- 


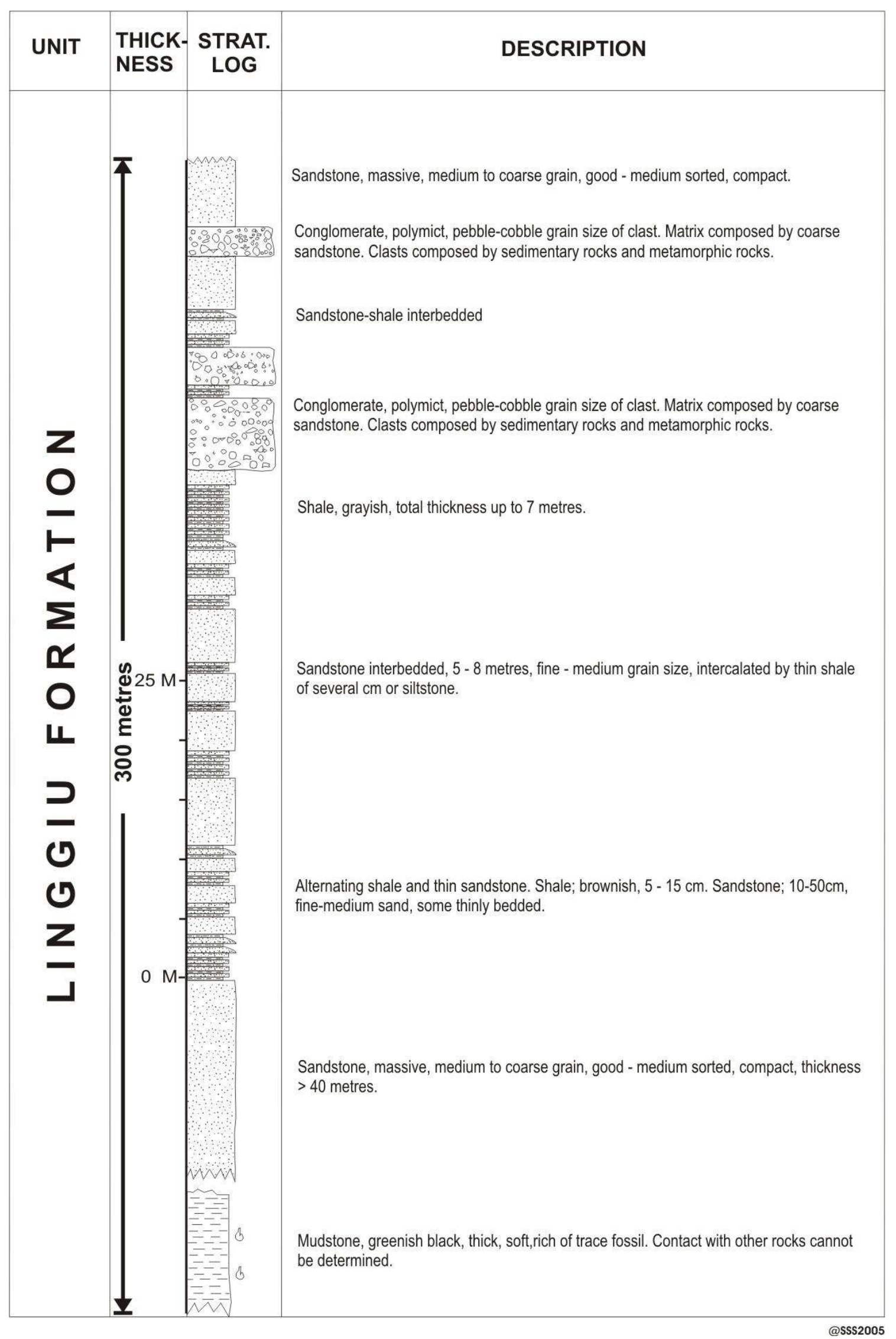

Figure 5: Lithological logs of Linggiu Formation with the conglomerate beds in upper succession 


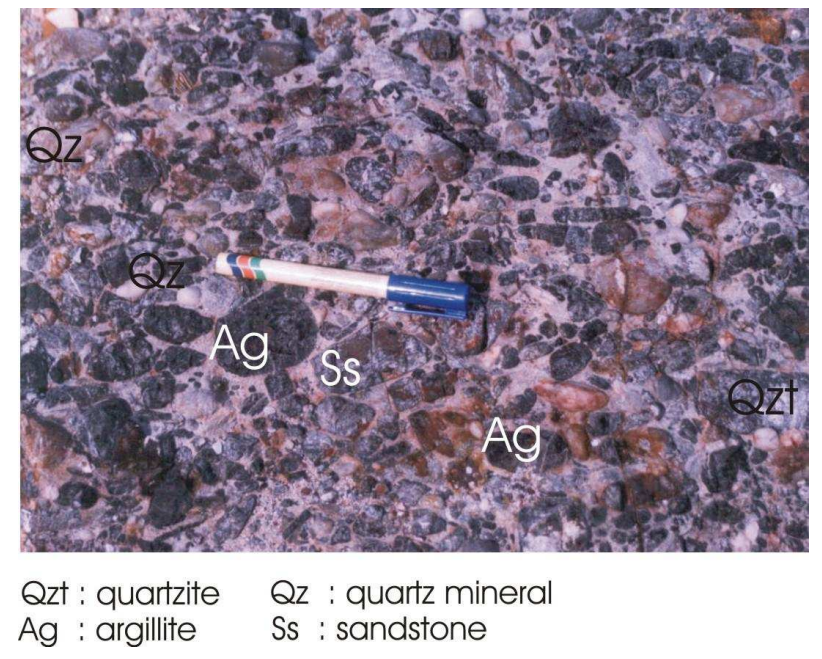

Figure 6: Polymict conglomerate of Tanjung Leman Formation in Tanjung Leman

erate unit in Tanjung Leman forms a small hill with rocky cliff facing the South China Sea. Another possibly occurrence of this formation is at Jeram Semagot areas (Suntharalingam, 1991), about for more than 11 kilometres west of Tanjung Leman. Surjono (2007) proposed this rocks unit as a formation tentatively the Tanjung Leman Formation separately from the Murau Formation.

The Tanjung Leman Formation is made up of metamorphic and sedimentary rocks with subordinate volcanic rock (Figure 6). Metamorphic rock fragments consist of argillite, slate, schist, phyllite and quartzite. Sedimentary rock fragments seem to be originated from Murau formation, as they are characterised by their reddish colour with angular clasts. Quartz is usually polycrystalline with well rounded texture, and rare subangular monocrystalline. Matrix of conglomeratic rocks consists of fine sandstone, while those in sandstone and siltstone are made up of clay-sized sediments and tuff. The matrix proportion in sandstone is usually less than $15 \%$, thus the framework normally displayed grain-supported fabric (bimodal conglomerate). Cement is usually made up of iron oxides.

The composite lithological log of the Tanjung Leman formation can be seen in Figure 7. The total measurable thickness from lithological log composite is about $80 \mathrm{~m}$. Sur- jono et al. (2004) has identified seven lithofacies from the Tanjung Leman Formation including the clast-supported, organized conglomerate facies (facies Gco), clast-supported, disorganized to poorly organized conglomerate facies (facies Gcd), clast-supported, inversegraded conglomerate facies (facies Gci), massive pebbly sandstone facies (facies $\mathrm{Sm}$ ), planarcross-bedded sandstone facies (facies $\mathrm{Sp}$ ), horizontally bedded sandstone facies (facies $\mathrm{Sh}$ ) and laminated sandstone, siltstone and mudstone facies (facies Fl). Following the Miall (1985)'s method, this lithofacies can be classified into three architectural elements (facies assemblages) based on their similar sedimentation process that are DOC (disorganized and organized conglomerate), GB (gravel bar and bedforms) and CLS (stacked conglomerate and laminated sand sheet sets) architectural elements. Facies assemblage DOC formed a very thick massive conglomerate comprises amalgamating or cross-cutting facies Gco and Gcd. It is determined at the bottom part of the lithological log. The thickness of this element reaches up 30 metres, and was characterized by subrounded to well rounded pebble- to cobblesized clasts dominant. According to Miall (1985), this channel floor bounding usually represent channel fill complex within fluvial system. For Tanjung Leman rocks, element DOC seems to be formed by combination of grainby-grain emplacement as well as high magnitute flood flows in fluvial system as interpreted by Jo and Chough (2001) for the northwestern part of Kyongsan Basin, Korea. The pebble-to cobble-sized clasts dominant indicated that it was transported by high energy.

The architectural element GB consists of facies Gcd and Sm with minor facies Gco, Sh and $\mathrm{Sp}$. This facies assemblage is well developed in the middle and bottom part of lithological log composite. The geometry of this element is characterized by interbedded of sandstone and conglomerate with erosional bases, laterally wedging and lensoidal boundaries represent filling of minor abandoned channel. Miall (1985) and Jo and Chough (2001) suggested this element as products of gravel bed river deposit with rapid scour fill. Maizels (1993) interpreted 


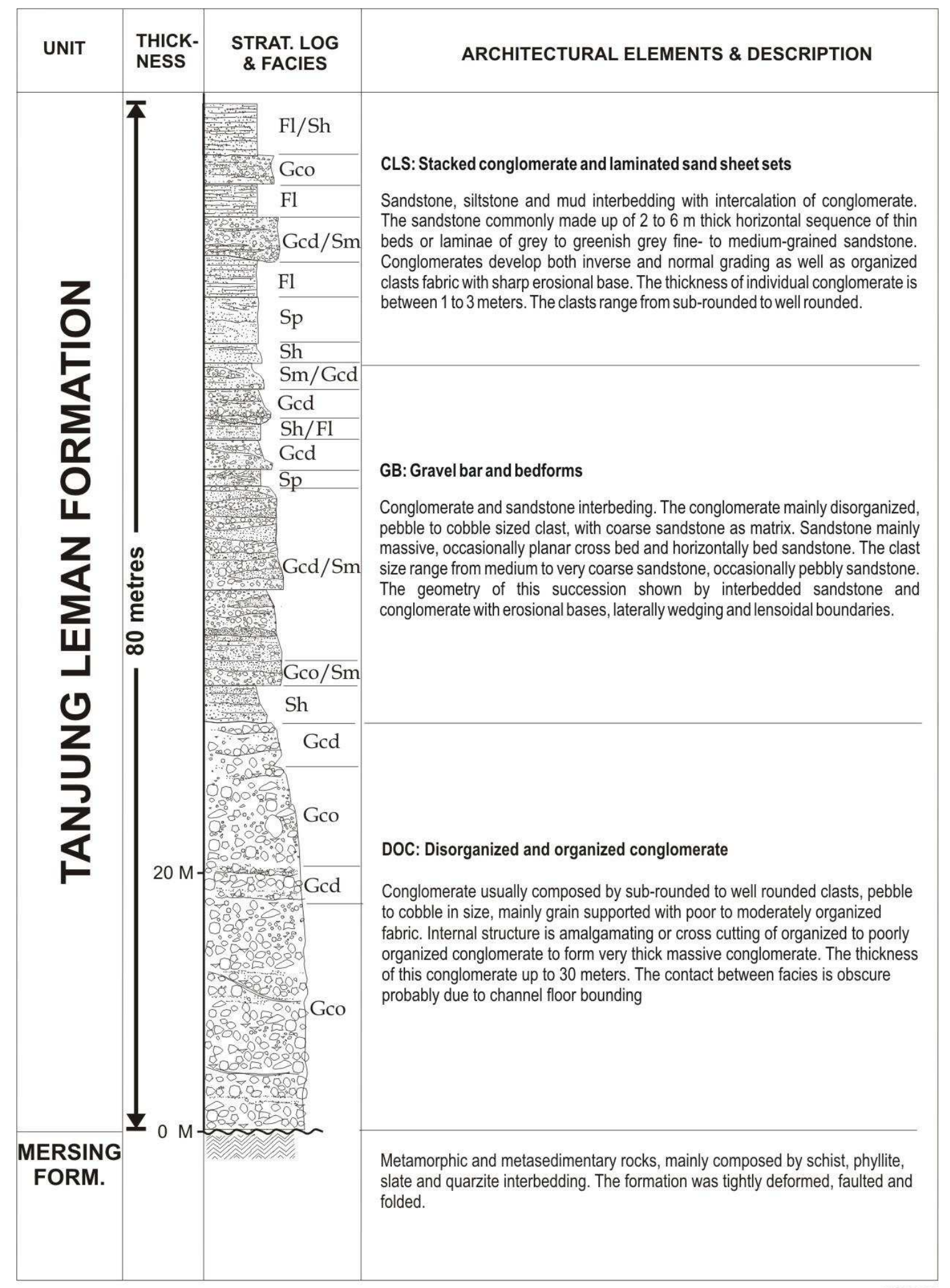

Figure 7: Lithological logs composite of the Tanjung Leman Formation 
this element as product of heavy sedimentladen flows during the waning of flood deposit.

The architectural element CLS comprises interbedded of thickly bedded sandstone and conglomerate. The sandstone is characterized by facies Sh, Fl and Sp, while facies Gco and Gci represent the conglomerate. The sandstone commonly forms as horizontal sequence of thin beds or laminae with fine- to mediumsized clasts. Conglomerates are characterized by inversely as well as normally graded bedding, lenses or gravel-scour and filled sedimentary structure. In Tanjung Leman, this architectural element was deposited above the GB element. This element was probably deposited from vertical accretion and downstream migration of broad, low-relief to planar bedforms. It usually represents distal, sheet flood and sand bed rivers. According to Jo et al. (1997), the presence of conglomerate within the sandstone represents the coarsest particles transported by streams flows. The lithofacies $\mathrm{Sh}$ and $\mathrm{Fl}$ as main component in this element is interpreted as bedding plane deposit either under high- to low-flow regimes. Miall (1985) suggested that the combination of facies Sh and Fl represents deposition from suspension to weak traction currents, common in overbank area.

The main source of the Tanjung Leman Formation is the metamorphic rocks of Mersing Formation, with subordinate sedimentary rocks of Murau Formation. The tuff within matrix and lapilli-size volcanic clasts indicates that the source of volcanic rocks is located of a distance from the river system of Tanjung Leman. Considering the recent geographic position, the hinterland area was occupied by the Mersing and Murau Formations located in west and northwest of Tanjung Leman river system.

\section{Stratigraphic correlation}

The base of the Murau Formation shows disconformity and angular unconformity with the Mersing Formation. These stratigraphic boundaries can be observed at Tanjung Murau and Pasir Landa. Whereas, based on the clasts content, the protolith of the Murau Formation is metamorphic rocks of Mersing Formation.
Therefore, the Murau Formation was most possibly deposited after the Early to Late Carboniferous (Surjono, 2007) uplifting and metamorphism of the Mersing Formation. Meanwhile, the absence of volcanic material in this formation also indicated that this formation was deposited prior to the extensive volcanism in East Johor, which was most probably initiated in Early Permian. Thus, the deposition of Murau Formation should be in Late Carboniferous.

According to Surjono (2006b), during the Early to Late Permian time, various rock types mainly siliciclastic and volcaniclastic rocks were deposited in the East Johor Basin. These rock types were contemporaneously deposited mainly in the shallow marine and partially in the subaerial depositional environments. These rock units can be classified into five formations, i.e., the Dohol, Linggiu, Sedili, Pengerang and Tanjung Leman Formations. The Sedili Formation is interfingering with the Dohol Formation as well as with Linggiu Formation. Dohol, Sedili and Linggiu Formations were deposited in shallow marine depositional environment within fore-arc basin. Conglomeratic rocks within Linggiu Formation were deposited during the sea level fall episode in the upper most succession. Surjono (2007) interpreted this episode correspond to closing of Sibumasu to Indochina-East Malaya continental blocks in the latest Permian. Based on the westwards palaeocurret directions of Dohol and Linggiu Formations, it is interpreted that the source area was located in the east. Provenance for these rock units mainly came from Mersing Formation mixed with volcanic rocks of the Sedili Formation.

The clastic rock formation that was deposited during the last period of volcanism in East Johor is the Tanjung Leman Formation. This formation occurs as isolated hill without lateral stratigraphic contact with other rock units. This formation was deposited in subaerial environment most likely during the final episodes of volcanism in East Johor. The volcanic clasts as well as matrix of Tanjung Leman rock unit possibly came from Sedili Formation distributed in central part of East Johor as well as those in the northern Mersing coast. The stratigraphic 


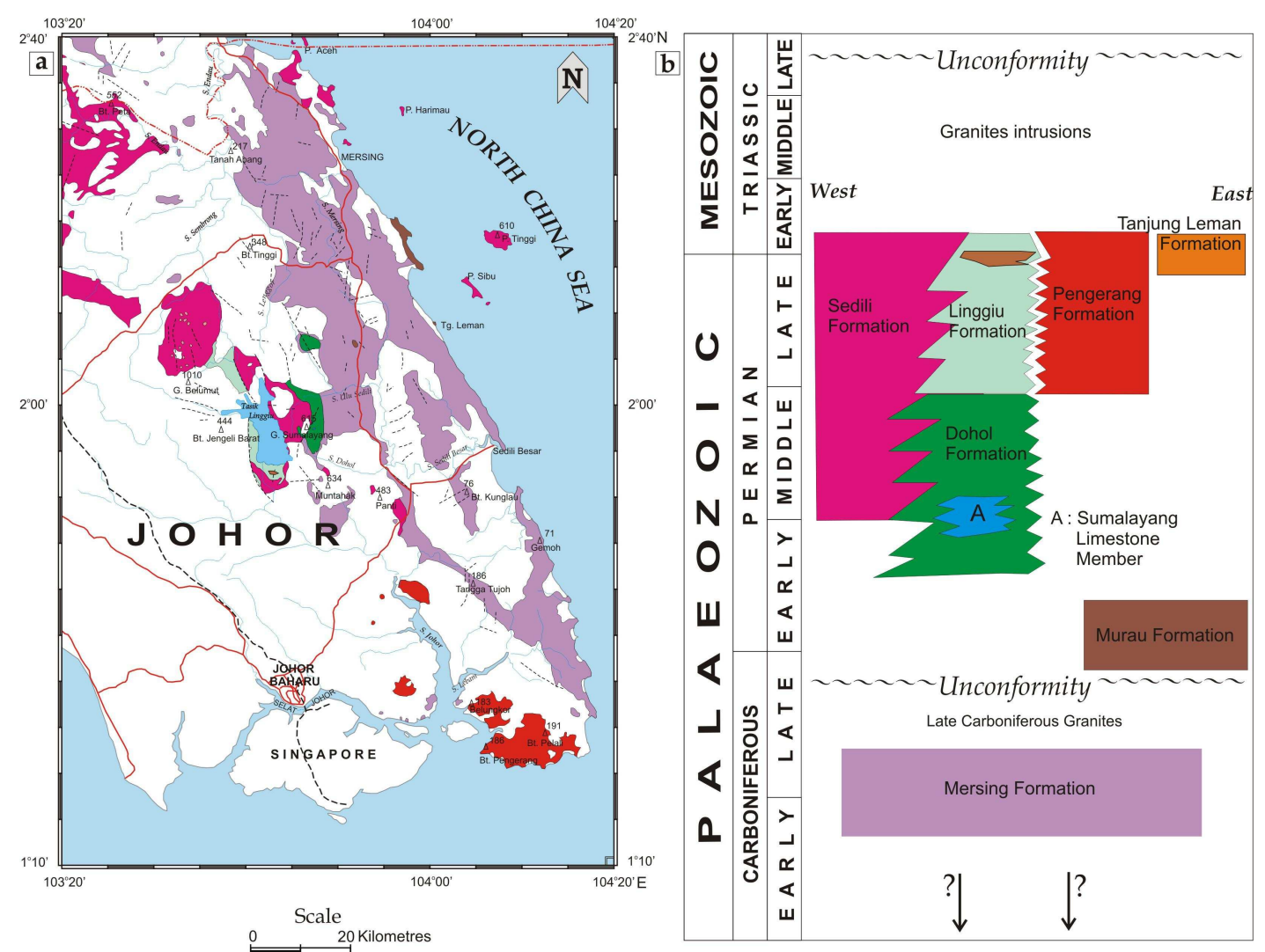

Figure 8: Stratigraphic correlation of Palaeozoic formations in East Johor

correlation among the Palaeozoic formations in East Johor is summarized in Figure 8 .

\section{Conclusions}

Among the Palaeozoic conglomeratic rocks in East Johor has its own characteristic indicate different sedimentary processes as well as depositional environments. They were deposited within separately basins and different geological time, therefore there are no genetically correlation between them. Depositional environment for all conglomeratic rocks range in subaerial to shallow marine indicate that East Johor of Peninsular Malaysia was a continental environment since Late Palaeozoic.

\section{Acknowledgement}

We wish to thanks the Ministry of Science, Technology and Innovation of Malaysia for granting the IRPA 02-02-02-0012-EA186 under which the field and laboratory works were carried out.

\section{References}

Boggs, S. Jr. 1992. Petrology of sedimentary rocks. New York: Macmillan Publishing Co.

Chough, S.K., Hwang, I.G. \& Choe, M.Y. 1990. The Miocene Doumsan fan-delta, Southeast Korea: A composite fan-delta system in back-arc margin. Journal of Sedimentary Petrology 60 : 445-455.

Dott, Jr. R.H. 1983. Episodic sedimentation-how normal is average? How rare is rare? Does it matter? Journal of Sedimentary Petrology 53: 5-23.

Dott, Jr. R.H. 1996. Episodic event deposits versus stratigraphic sequences-shall the twain never meet? Sedimentary Geology 104: 243-247.

Einsele, G. 1996. Event deposit: the role of sediment supply and relative sea-level changes - overview. Sedimentary Geology 104: 11-37.

Hutchison, C.S. 1989. Geological evolution of Southeast Asia. New York: Oxford University Press.

Igo, H., Rajah, S.S. \& Kobayashi, F. 1979. Permian Fusulinaceans from Sungai Sedili area, Johore, Malaysia. Geology and Paleontology of Southeast Asia 20: 95-118.

Jo, H.R. \& Chough, S.K. 2001. Architectural analysis of fluvial sequences in the northwestern part 
of Kyongsan Basin (Early Cretaceous), SE Korea. Sedimentary Geology 144: 307-334.

Jo, H.R., Rhee, C.W. \& Chough, S.K. 1997. Distinctive characteristics of a streamflow-dominated alluvial fan deposit: Sanghori area, Kyongsan Basin (Early Cretaceous), southeastern Korea. Sedimentary Geology 110: 51-79.

Kon'no, E., Asama, K. \& Rajah, S. 1971. The Late Permian Linggiu Flora from the Gunung Blumut Area, Johore, Malaysia. Geology and Paleontology of Southeast Asia 9: 1-85.

Maizels, J. 1993. Lithofacies variations within Sandur Deposits: the role of runoff regime, flow dynamics and sediment supply characteristics. Sedimentary Geology 85: 299-325.

Miall, A.D. 1985. Architectural-element analysis: a new method of facies analysis applied to fluvial deposits. Earth- Science Reviews 22: 261-308.

Prothero, D.R. \& Schwab, F. 2004. Sedimentary geology: an introduction to sedimentary rocks and stratigraphy. New York: W.H. Freeman and Company.

Raymond, L.A.1995. Petrology. London: Wm.C. Brown Publishers

Suntharalingam, T. 1991. Geology and mineral resources of the Hulu Sedili area, Johor Darul
Ta'zim. Geological Survey of Malaysia Map Report 2. 86pp.

Surjono, S.S. 2007. Stratigraphy and Sedimentology of the East Johor Palaeozoic Basin, Peninsular Malaysia. PhD Thesis, Universiti Kebangsaan Malaysia (in prep)

Surjono, S.S., Leman, M.S., Mohamed, K.R., and Ali, C.A. 2004. Lithofacies and architectural elements of conglomerate in Tanjung Leman, East Johor, Malaysia. Abstract and Program of Annual Petroleum Conference, Geological Society of Malaysia. pp. iv-vii (paper 23).

Surjono, S.S., Leman, M. S., Mohamed, K.R., \& Ali, C.A. 2006a. Sedimentary facies development of breccia deposit in Tanjung Sekakap-Tanjung Murau area, Mersing, Johor, Peninsular Malaysia. Geological Society of Malaysia Bulletin 49: 157167.

Surjono, S.S, Leman, M. S, Ali, C.A., \& Mohamed, K.R. 2006b. A review of the Palaeozoic lithostratigraphy of East Johor, Malaysia. Geological Society of Malaysia Bulletin 49: 71-78.

Walker, R.G., 1975. Generalized facies model for resedimented conglomerates of turbidite association. Geological Society of America Bulletin 86: 737-748. 